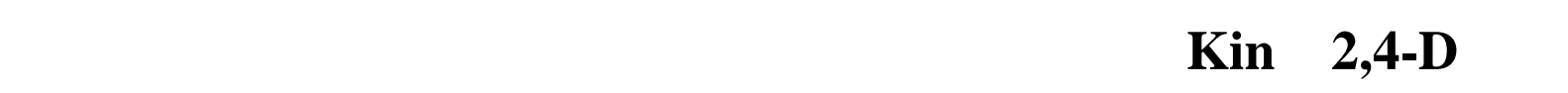 Nigella sativa L. الحبة اللسوداء
}

\author{
هiاعسعيد الصالح \\ قصم علوم الحية \\ كلية العلوه \\ جلمعة الموصل
}

\author{
a مهالمحدطa النييمي \\ المعرد الثقي \\ الموaل
}

(تاريخ الاستلام 1/ 3 / 2010 ؛ تاريخ القبول 26 /4 / 2010)

\section{الملغص}

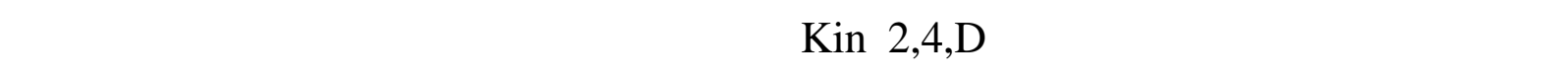
اللسوداء Nigella sativa L و بالترلكيز

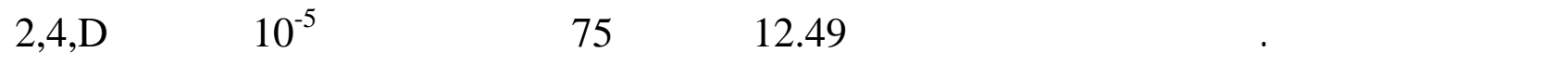

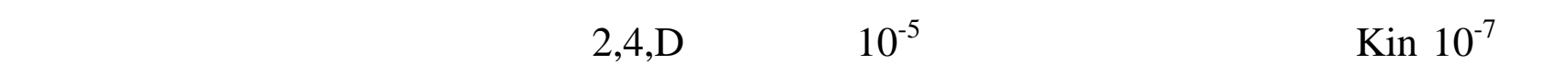

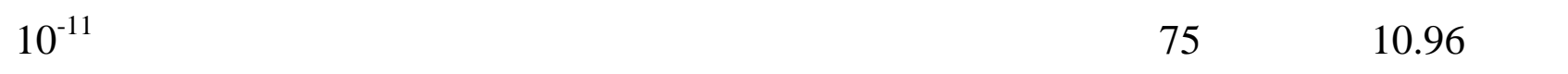

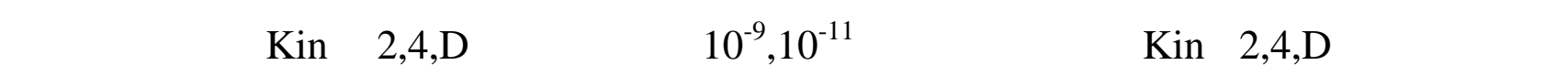
مقهت أفضل نمو للجذور. إلى جالب ذلك أوضهت الدرلسة دور مركب للسفانيل أمايد في لستحداث ونمو الكاللس لنبت الحب

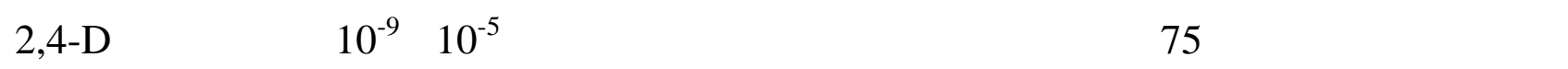

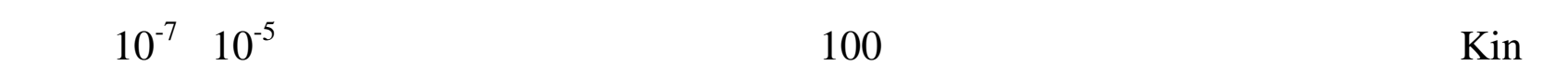

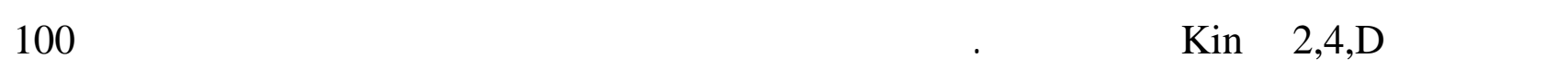

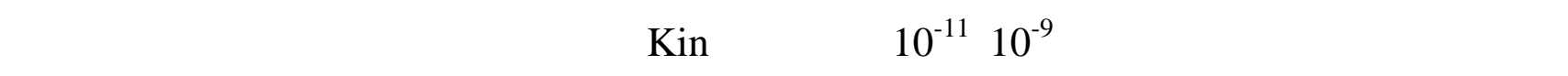

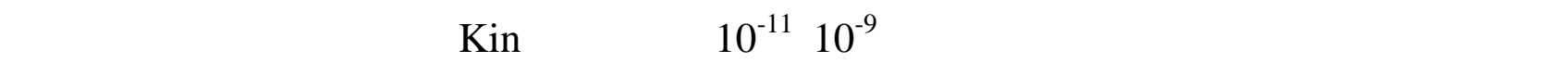
الجذور. وأثبتت نتائج الدرلسة وجود تباين في محتوى الكالس اعتمادا على تركيز ونوع مظفم النمو المستخدم مقارنة مع الثايمول القيلسي. 
مها محمدطه النعيهي و هناعسعيد الصالح

\title{
The Effect of 2,4-D and Kin and their Interaction with Sulphanilamide in Initiation and Growth of Black Cumin Nigella sativa L. Callus
}

\author{
Maha M. Al-Noaimy \\ Technical Institute
}

Mosul

\author{
Hana S. AL-Saleh \\ Department of Biology \\ College of Science \\ Mosul University
}

\begin{abstract}
The study deals with the role 2,4-D and Kin and their interaction in callus induction , growth and differentiation from Nigella sativa L. which were used in $\left(10^{-3}, 10^{-5}, 10^{-7}, 10^{-9}\right.$, $10^{-11}$ ) molar for each and by their interaction with each other. The results showed the best enhancement media are that contain $10^{-5} \mathrm{M}$ of 2,4-D with $10^{-7} \mathrm{M}$ of the Kin in which the fresh weight of the growing callus $12.49 \mathrm{~g}$, by the age that lasts 75 days, followed by the medium containing $10^{-5} \mathrm{M}$ of 2,4-D alone in which the fresh weight of the callus reached to $10.96 \mathrm{~g}$ in 75 days.

The results showed also the best differentiation of the shoots happened in the media supplemented with $10^{-11}$ for each 2,4-D and Kin,While addition of $10^{-11}, 10^{-9}$ of both 2,4-D and Kin had achieved the best growth for the roots.

The study induced knowing the role of ( Sulphanilamide ) a chemical compound in initiation, growth and differentiation of Nigella sativa. It was clear that the best enhancement media for callus initiation and growth are that containing suphanilamide by 75 micromollar with $10^{-5}, 10^{-9} \mathrm{M}$ for 2,4-D and Kin, also the media fortified by 100 micromollar of sulphanilamide alterating with $10^{-5}, 10^{-7} \mathrm{M}$ for 2,4-D and Kin, as for shoots enhancement the best results were obtained after using the media containing 100 micromollar of sulphanilamide with $10^{-9}, 10^{-11} \mathrm{Mr}$ of Kin .

Results also showed variation of the callus content of thymol comparing them by the thymol extract (control sample). The variation depended on the type and concentration of the growth regulators used.
\end{abstract}

